\title{
CULTUROLOGY
}

\section{THE DEVELOPMENT OF MODERN CHINESE CULTURE IN INFORMATION ERA}

\author{
N. Rasuleva ${ }^{1}$ \\ DOI: http://doi.org/10.15350/L_21/3/2
}

\begin{abstract}
With the coming of the information era, new science and technology develops rapidly and the Internet gets further application. At present, the Internet becomes an indispensable tool in our daily life. What's more, Internet has deep influence on the development of modern Chinese culture. The Chinese civilization, extensive and profound, and with a long history behind it, has contributed tremendously to the progress of human civilization. Internet, an important medium for cultural activities, becomes one of the main influencing factors on the development of Chinese culture.
\end{abstract}

Keywords: Modern Chinese culture; information era; Internet.

\section{Introduction}

Stepping into the 21th century, the science and technology develop at a high speed. Many new things are springing up and the old ideas and concepts cannot fit into the mainstream of society. New technologies have transformed the world thoroughly. Great science and technologies have promoted social development and improved people's living standards. Internet has become an indivisible part of modern life. Chinese culture cannot avoid the clash of Internet despite it has a history of five thousand years. Under this tremendous influence, Chinese culture is lapsing into a new way of development.

\section{The Significant Features of Modern Chinese Culture}

Modern Chinese culture is facing the problem of selecting a proper way of development at present. Under the great power of Internet, many fresh things have challenged the traditional ideas in Chinese culture. But the Chinese culture still remains its significant features.

\footnotetext{
${ }^{1}$ Nigina Rasuleva, Ph.D. student in Chinese Linguistics and Modern Literature, Shanghai University, People's Republic of China.
} 
As Professor Raymond Williams, an English historian of culture said, "Culture was one of the most difficult terms to define." There are many definitions of culture given by the former researches in cultural field.

E.A. Hoebel \& E.L. Frost sees culture as the "integrated system" of "learned" behavior patterns. The define culture as "integrated system of learned behavior patterns which are characteristic of the members of a society and which are not the result of biological inheritance." (Xie Yuchun, 2002) [2, c.4-5]

The definition above describes culture in a more detailed way. It can be found that culture is the living ways of the certain social members. It contains all the information that how the members cope their world, with others even with themselves. All these are not material, being not seen or touched. So culture is not a kind of material definition, but a spiritual phenomenon. To discuss Chinese culture, the spiritual fundamental should be discussed. Chinese culture obtains its unique and characteristic supports from its social members.

\section{A.Large Population Involved in Culture}

From the definitions of culture above, the writer finds that culture is related to people, society and nation. Since culture is spiritual, it must cling to a material foundation-people. So human beings play an important role in the development of culture, especially in China.

\section{B.The Participation of Each Social Class in Culture}

Since there are such a large number of people contributing to the development of Chinese modern culture, they have to follow some certain rules. If not, everything will be in a mess. According to Professor Yang Saiwei, culture is a kind of formalized and systematized social structure. All social classes are the frameworks of the social structure. However, people belonging to different social classes live in different environments. They have different lifestyles, receive different levels of education and face different challenges and obstacles. So their attitudes towards culture must be different. Even in some developed countries, there is a huge cultural gap between the elite class in the governing position and the general public [4].

\section{C.Self-creation of Chinese Culture}

Under the influences of Internet, many fresh phenomena appear in China. The active participation of all social class is just one new aspect in Chinese modern culture. More and more new things are created with the help of Internet. Internet also helps Chinese people to form some new habits. These are the new exhibitions of Chinese culture. So for the development of culture, Internet makes a great contribution as major exterior strength. Although Internet is such a big impetus, this paper does not consider that it can replace the effect of culture itself $[1$, c.3-6]. 
The Chinese four-character idiom, Chinese traditional symbols of deep meanings, is the essential heritage of Chinese traditional culture. It is still useful in daily education nowadays. Besides, facing the development of modern life, many Chinese idioms have been endowed with new meaning. Some are used for fun. Such as the idiom “Man Di Zhao Ya" (满地找牙), whose original meaning is beating someone badly. And many characters and phrases are given new meanings, too. For example, the character "Lei" (雷) mentioned before. It is the name of thunder in Chinese formerly. But now, it is used to describe the embarrassing feelings or the feelings of hearing black humors. Besides, there are also some words given some new meanings, such as "Shan Zhai" (山寨) and "Jiong"

(周), which are very familiar to Chinese people [5].

3.The Main Factors Influencing the Development of Modern Chinese Culture

The Chinese civilization is profound and has a long history, having experienced ups and downs. Culture is the spirit of a nation and driving force for national development. Therefore the development of modern Chinese culture plays an integral part of the process of China. To have the right awareness of the development of modern Chinese culture, the writer argues the main factors which strongly influence modern Chinese culture.

\section{A.Transformation of Social Environment in information era}

With the end of the cold war, the trends towards a multi-polar world developed in greater depth and the peace and development became two major issues in the world. The global circumstances were relatively safe and steady, which provided a hotbed for the development of science and technology. The rising science and industrial revolution has totally changed people's life.

The emergence of the Internet has changed the layout of world resources. With the further application of the Internet people's lifestyles have changed greatly. The internet promotes intercultural communications personalized development of culture, which has a profound effect on modern Chinese culture [1, c.3-6].

\section{B.Influence of the Western Culture caused by Globalization}

Globalization is the process of international integration arising from the interchange of world views, ideas, concepts, and other aspects of culture. In recent years, globalization has greatly increased the frequency of international exchanges. With the political and economic development, the world has been led to a global village. Western cultures provide abundant reference experience for us, which helps us improve the competitiveness of natural industry. It is inevasible that the development of modern Chinese culture is influenced by the other culture systems.

C.Renaissance of Traditional Chinese Culture 
Culture is splendid but fragile. Chinese culture is the treasure in the history of world civilization, but has faced multiple challenges since 19th century. In modern society, the emergence of new wave of Chinese classics craze indicates the revival of traditional Chinese culture, which is a good sign. China's Confucius institutes around the world are about spreading appreciation for Chinese culture and language. In addition, with governments' popularization of the importance of traditional Chinese culture more and more Chinese people value traditional festivals and customs.

\section{Conclusion}

China is an ancient civilization with more than five thousand years of history. Chinese culture is longstanding and successive, being considered as one of the oldest ancient civilizations. With rapid economic and political development as well as globalization, the phenomenon of intercultural communications is more common. Chinese culture absorbs essence from other cultures and still remains its unique characteristic. Modern Chinese culture becomes more prosperous due to cultural inclusiveness. At present, cultural soft power plays an important role in comprehensive national strength. Therefore governments are taking measures to encourage people to learn more about Chinese culture in order to increase the influence of Chinese culture in the world. Indeed, more and more people from home and abroad pay more attention to Chinese culture, which can help them better know about China.

\section{References:}

[1] Xie Yuchun. Appreciation of Translations: A Cross-cultural Perspective, University of Electronic Science and Technology of China.,2002.

[2] Zheng Zhuxuan. Translation and Chinese culture. Fujian Normal University.,2002.

[3] 汤一介。新轴心时代与中国文化的建构。江西人民出版社.,2007.

[4] 郭镇之。全球化与文化间传播。北京广播学院出版社。2004.

[5] 关世杰。试论国际传播研究与跨文化交流研究的异同与互补。北京广播学院出版 社。 2004. 